\title{
Response of root traits of Reaumuria soongorica and Salsola passerina to facilitation
}

\author{
HaiNa ZHANG ${ }^{1,2}$, PeiXi SU ${ }^{1,2^{*}}$, ShanJia $\mathrm{LI}^{1,2}$, ZiJuan ZHOU ${ }^{1,2}$, TingTing XIE ${ }^{1}$ \\ ${ }^{1}$ Linze Inland River Basin Research Station, Cold and Arid Regions Environmental and Engineering Research Institute, \\ Chinese Academy of Sciences, Lanzhou 730000, China; \\ ${ }^{2}$ Key Laboratory of Land Surface Process and Climate Change in Cold and Arid Regions, Chinese Academy of Sciences, \\ Lanzhou 730000, China
}

\begin{abstract}
C}_{3}$ plant Reaumuria soongorica and $\mathrm{C}_{4}$ plant Salsola passerina are super xerophytes and coexist in a mixed community in either isolated or associated growth, and interspecific facilitation occurs in associated growth. In the present study, the root traits including root distribution, root length (RL), root surface area (RSA), root weight (RW) and specific root length (SRL) of both species in two growth forms were investigated to clarify their response to facilitation in associated growth. Six isolated plants of each species, as well as six associated plants similar in size and development were selected during the plant growing season, and their roots were excavated at $0-10,10-20,20-30,30-40$ and $40-50 \mathrm{~cm}$ soil depths at the end of the growing season. All the roots of each plant were separated into the two categories of fine roots $(<2 \mathrm{~mm}$ diameter) and coarse roots $(\geq 2 \mathrm{~mm}$ diameter). Root traits such as RL and RSA in the fine and coarse roots were obtained by the root analyzing system WinRHIZO. Most of the coarse roots in $R$. soongorica and $S$. passerina were distributed in the top $10 \mathrm{~cm}$ of the soil in both growth forms, whereas the fine roots of the two plant species were found mainly in the 10-20 and 20-30 cm soil depths in isolated growth, respectively. However, the fine roots of both species were mostly overlapped in 10-20 $\mathrm{cm}$ soil depth in associated growth. The root/canopy ratios of both species reduced, whereas the ratios of their fine roots to coarse roots in RL increased, and both species had an increased SRL in the fine roots in associated growth. In addition, there was the increase in RL of fine roots and content of root $\mathrm{N}$ for $S$. passerina in associated growth. Taken together, the root growth of $S$. passerina was facilitated for water and nutrient exploration under the interaction of the overlapped roots in both species in associated growth, and higher SRL allowed both species to more effectively adapt to the infertile soil in the desert ecosystem.
\end{abstract}

Keywords: $\mathrm{C}_{3}$ plant; $\mathrm{C}_{4}$ plant; facilitation relationship; root traits; specific root length

Citation: HaiNa ZHANG, PeiXi SU, ShanJia LI, ZiJuan ZHOU, TingTing XIE. 2014. Response of root traits of Reaumuria soongorica and Salsola passerina to facilitation. Journal of Arid Land, 6(5): 628-635. doi: 10.1007/s40333-014-0024-6

Interspecific facilitation occurs when one species positively alters the environment of another (Hogh-Jensen and Schjoerring, 2000), and this process seems to be particularly important in xeric regions (Maestre et al., 2003; Rossi and Villagra, 2003; Oesterheld and Oyarzabal, 2004; Larrea-Alcázar et al., 2005). The importance of facilitation increases along a gradient of abiotic stress (Maestre et al., 2003). However, for many decades negative interactions have been consid- ered to be the major force driving interspecific interactions in plant communities (Keddy, 1989). In the past two decades, there has been an increasing interest in facilitation, and its importance for plant community dynamics is widely recognized (Bertness and Callaway, 1994). Facilitation has been extensively documented all over the world and in different climates (Bertness and Ewanchuk, 2002; Cavieres et al., 2002; Holl, 2002; Gomez-Aparcio et al., 2004), and

*Corresponding author: PeiXi SU (E-mail: supx@lzb.ac.cn)

Received 2013-07-23, revised 2013-10-28, accepted 2013-12-03

(C) Xinjiang Institute of Ecology and Geography, Chinese Academy of Sciences, Science Press and Springer-Verlag Berlin Heidelberg 2014 
the related literatures have reported the facilitation of grass establishment by shrubs, or of shrub and tree seedlings by adults, either conspecific or not (Franco and Nobel, 1989; Moro et al., 1997; Pugnaire and Luque, 2001); however, facilitation between adult shrubs in desert ecosystems has rarely been reported.

The mechanisms of facilitation in harsh conditions are diverse, such as improving soil fertility (Moro et al., 1997), ameliorating microenvironment (Franco and Nobel, 1989), and increasing water availability (Raffaele and Veblen, 1998) under the canopy of facilitator species. Water and nutrient acquisition in poor and arid environments depends on both physiological and morphological plant traits, as well as on the habitat type (Aerts and Chapin III, 1999). Nevertheless, the morphological traits of plants are more important than the physiological traits for the acquisition of slowly diffusing nutrients in the soil with less water content (Aerts, 1998), and both facilitation and competition are triggered by root competition (Yeaton and Esler, 1990; Esler and Cowling, 1993; Carrick, 2003). Plants may allocate more biomass to their root systems in order to increase resource uptake, or they may show adaptive changes in their root morphology by having a higher root length per unit root mass (SRL) (Aerts, 1998). Species with a relatively higher SRL may be at an advantage in exploiting pulses of water or nutrients in the soil (Eissenstat, 1991). The functional attributes of root systems (e.g. SRL, tissue nitrogen $(\mathrm{N})$ and carbon $(\mathrm{C})$ content, ratios of fine roots to coarse roots, distribution of roots in soil, etc.) are determinants of both ecosystems and plant community dynamics, including belowground resource and water acquisition, net primary production, and competitive interaction (Craine et al., 2003; Shiponeni et al., 2011). Fine roots $(<2 \mathrm{~mm}$ diameter $)$ should have greater specific acquisition rates and affect microbial decomposition more than coarse roots ( $\geq 2 \mathrm{~mm}$ diameter) (Trumbore and Gaudinski, 2003).

$\mathrm{C}_{3}$ plant Reaumuria soongorica and $\mathrm{C}_{4}$ plant Salsola passerina are dominant and super-xerophytic species and form the top community in the eastern part of the desert and desert grassland regions of China (Qiu and Liu, 1982). R. soongorica, belonging to the Tamaricaceae, is a perennial undershrub with short cylinder-shaped leaves, and S. passerina, belonging to the Chenopodiaceae, is a fasciculate semishrub with dense branches and fleshy leaves. $R$. soongorica germinated in later April, blossomed in late July, and fruited in mid-August, whereas S. passerina germinated in late April, with a flowering phase lasting from June to September and fruiting phase lasting from August to September. In particular habitats, $R$. soongorica and $S$. passerina coexist in a mixed community in either isolated or associated growth. Su et al. (2012) found that the net photosynthetic rate in $R$. soongorica was facilitated when the plant species were grown with $S$. passerina.

In the present study, to understand the response of root traits to the interspecific facilitation between $R$. soongorica and S. passerina in associated growth, we investigated the root traits of both species in isolated and associated growths, seeking to clarify the following questions: Under the facilitation in associated growth, how do the roots in $R$. soongorica develop in the direction of acquiring more water and nutrients to satisfy higher photosynthetic demand? And how does $S$. passerina coordinate its roots to facilitate the aboveground growth of $R$. soongorica?

\section{Materials and methods}

\subsection{Study area}

The study was carried out in a typical Gobi desert located in the middle reaches of the Heihe River $\left(38^{\circ} 54^{\prime} 05.1^{\prime \prime} \mathrm{N}, 100^{\circ} 15^{\prime} 46.7^{\prime \prime} \mathrm{E}\right.$; $1,590 \mathrm{~m}$ asl), the second largest inland river in the arid northwest China. The soil is classified as gray brown desert soil with a high gravel content (Liu et al., 2012). The gravel content and size increase as soil depth increases. The organic matter content is less than $3 \%$. The area is characterized by a temperate continental climate, with an annual precipitation of $129 \mathrm{~mm}, 70 \%$ of which occurs between June and September, an annual potential evaporation of 2,048 mm, which is nearly 16 times of the precipitation, an annual mean temperature of $7.0^{\circ} \mathrm{C}$ with an average minimum daily temperature of $-14.7^{\circ} \mathrm{C}$ in January and an average maximum daily temperature $29.6^{\circ} \mathrm{C}$ in July, and an annual sunshine duration of $3,045 \mathrm{~h}$. The mixed plant community is mainly composed of $R$. soongorica and $S$. passerina, with the total vegetation coverage being about $10 \%$, among which $R$. soongorica and S. passerina account for $4 \%$ and $6 \%$, respectively (Yan et al., 2012). Other 
accompanying plants are Convolvulus tragacanthoides, Eragrostis poaeoides, Halogeton glomeratus and Asterothamnus centrali-asiaticus, the coverage of which is less than $1 \%$.

\subsection{Experimental design}

In the plant growing season, six isolated adult plants of each species and six associated adult plants growing vigorously and similar in size were randomly selected in the study field. Two perpendicular diameters (one of which was the longest possible) and the height of each individual plant were recorded. The distance between the associated plants was a maximum of $5 \mathrm{~cm}$. No plants were closer than $1.5 \mathrm{~m}$ from the selected plants to avoid inter- and intra-specific interactions. The associated growth of $R$. soongorica and $S$. passerina was shown in Fig. 1.

At the end of the growing season (late September, 2012), all the selected plants in isolated and associated growths were excavated by means of the trench method, with the circular trench being $20 \mathrm{~cm}$ in width and $50 \mathrm{~cm}$ in depth. Excavation continued up to $50 \mathrm{~cm}$ where a hardpan was developed and further excavation was very difficult, but roots from above $50 \mathrm{~cm}$ were nearly the total root mass. Excavation was done by hand using a pointed wooden stick to loosen the soil which was then hand removed, leaving the root system intact. All of the aboveground and belowground samples were collected in separate paper bags, then placed in an ice box, sealed, and brought to the laboratory. The root data for $R$. soongorica and $S$. passerina in both growth forms were collected at the following depth categories: 0-10, 10-20, 20-30,
$30-40$ and $40-50 \mathrm{~cm}$. At the same time, every $20 \mathrm{~cm}$ soil layer above $80 \mathrm{~cm}$ soil depth was sampled using soil augers to measure the water content of the soil dry mass. Soil samples were replicated three times per 20 $\mathrm{cm}$ soil layer, then brought to the laboratory, dried to constant weight at $105^{\circ} \mathrm{C}$, and weighed.

All the roots were washed to remove sediment and impurities, separated into fine roots $(<2 \mathrm{~mm}$ diameter $)$ and coarse roots $(\geq 2 \mathrm{~mm}$ diameter) (Trumbore and Gaudinski, 2003; Wilcox et al., 2004), then dyed in $0.5 \%$ methyl blue for $12 \mathrm{~h}$, and scanned (Canon Scan Lide110, Japan). The morphological characteristics of the roots, such as root length (RL) and root surface area (RSA) of the fine and coarse roots, were obtained by the root analyzing system WinRHIZO. Next, all of the aboveground and underground samples were separated, put in envelopes, dried to a constant weight at $80^{\circ} \mathrm{C}$, weighed (canopy weight, fine root weight and coarse root weight), and then pulverized into fine powders for nutrient analysis. Specific root length (SRL) was defined as the root length per unit root biomass.

Total $\mathrm{N}$ and total $\mathrm{C}$ were determined using the dry combustion method with an Elemental Analyzer Vario MACRO CUBE (German Elementar) in the soil laboratory of the Cold and Arid Regions Environmental and Engineering Research Institute, Chinese Academy of Sciences.

\subsection{Data analysis}

All the statistical analysis was performed using SPSS 16.0 software (SPSS, Inc., Chicago, IL, USA). The differences of plant morphology, root traits and plant

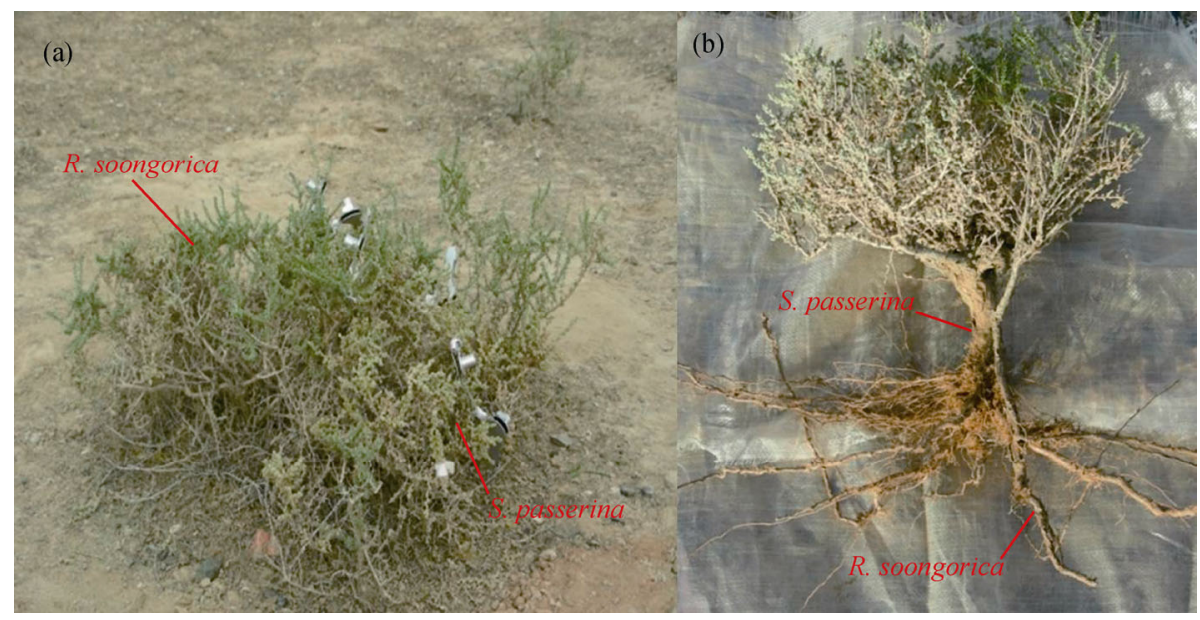

Fig. 1 The aboveground and underground characteristics of $R$. soongorica and S. passerina in associated growth 
biomass of $R$. soongorica and $S$. passerina between isolated and associated growths were analyzed by independent $t$ test. The figures in the present study were presented by Origin 8.0.

\section{Results}

Soil water content in the desert habitat depends on the rainfall. Most of the soil water was stored in the top $40 \mathrm{~cm}$ of the soil, with the soil water content being above $1.2 \%$. The soil water content decreased sharply with an increase in soil depth. Under the $40 \mathrm{~cm}$ soil depth, the soil water content was steady and less than $0.4 \%$ (Fig. 2).

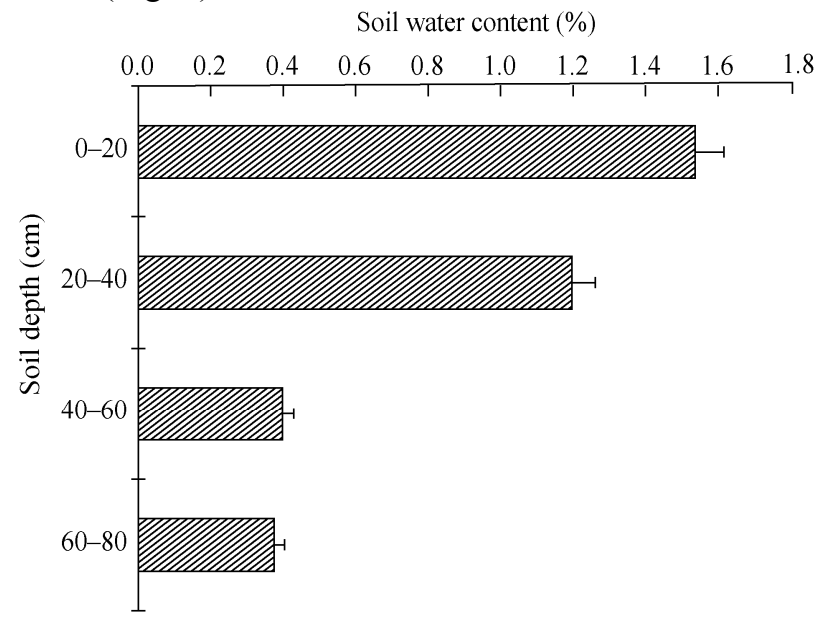

Fig. 2 Soil water contents in different soil depths, $n=3$.

In general, both canopy dimensions and heights of $R$. soongorica and $S$. passerina were similar, but their root systems were significantly different. Compared with the shallow and broad roots in $S$. passerina $(43.2$ $\mathrm{cm} \times 46.1 \mathrm{~cm}), R$. soongorica showed deep and narrow roots $(74.1 \mathrm{~cm} \times 18.1 \mathrm{~cm})($ Table 1$)$. In terms of vertical root distributions, about $90 \%$ of the total root mass of $R$. soongorica and $S$. passerina were in the top $30 \mathrm{~cm}$ of the soil, and nearly all of the coarse roots of both species were distributed in the top $20 \mathrm{~cm}$, and decreased with soil depth (Fig. 3). Most of the fine roots in $R$. soongorica occurred at the $10-20 \mathrm{~cm}$ depth, where the fine roots were much higher in associated growth than in isolated growth, while the fine root mass in the top $10 \mathrm{~cm}$ and at the 20-30 cm depth reduced markedly in associated growth (Figs. 3a and c).
Different from $R$. soongorica, the fine roots of S. passerina increased at the $0-30 \mathrm{~cm}$ soil depth and decreased below the $30 \mathrm{~cm}$ depth in isolated growth, while in associated growth, the fine roots were distributed most at the 10-20 cm depth and then sharply reduced below the $20 \mathrm{~cm}$ soil depth with an increase in the soil depth. This indicated that $S$. passerina developed more fine roots on the top soil depth in associated growth than in isolated growth (Figs. 3b and d). In associated growth, the roots of $R$. soongorica and $S$. passerina were more overlapped at the $10-20 \mathrm{~cm}$ soil depth (Figs. 3c and d).

Compared with isolated growth, $R$. soongorica and $S$. passerina showed no clear difference in terms of canopy biomass, but had a significantly lower root biomass in associated growth. The root biomass of $R$. soongorica and $S$. passerina in isolated growth were 1.65 and 1.75 times as much as those in associated growth, respectively, inducing significantly lower root to canopy ratios in both species in associated growth (Table 2).

$R$. soongorica had lower RL, RSA and RW in both fine roots and coarse roots in associated growth than in isolated growth, with the exception of RL in fine roots and RSA in coarse roots (Figs. $4 \mathrm{a}-\mathrm{c}$ ). However, a notably higher SRL in the fine roots of $R$. soongorica occurred in associated growth (Fig. 4d). For $S$. passerina, the RL and SRL of the fine roots were significantly higher in associated growth than in isolated growth (Figs. 4e and h), while the RSA and RW showed similar values in the fine roots for the two growth forms, and significantly decreased values in the coarse roots in associated growth (Figs. 4f and $\mathrm{g}$ ).

The ratios of fine roots to coarse roots in $R$. soongori$c a$ were significantly higher in RL and lower in RSA in associated growth than in isolated growth. For $S$. passerina, the ratios of RL, RW and RSA were much higher in associated growth than in isolated growth (Table 3 ). In addition, it could be seen that $R$. soongorica had a significantly lower $\mathrm{N}$ content in associated growth than in isolated growth, while the root $\mathrm{N}$ content in $S$. passerina in both growth forms was opposite to that in $R$. soongorica. In terms of root $\mathrm{C}$ content, neither $R$. soongorica nor $S$. passerina showed significant differences between the two growth forms (Fig. 5). 
Table 1 Basic status of $R$. soongorica and S. passerina in the mixed community

\begin{tabular}{lccc}
\hline Species & Height $(\mathrm{cm})$ & Canopy diameter $(\mathrm{cm} \times \mathrm{cm})$ & Root depth $(\mathrm{cm})$ \\
\hline R. soongorica & $24.5 \pm 3.6^{\mathrm{a}}$ & $(25.3 \pm 5.3) \times(23.3 \pm 4.5)^{\mathrm{a}}$ & $74.1 \pm 6.8^{\mathrm{a}}$ \\
S. passerina & $18.4 \pm 2.5^{\mathrm{a}}$ & $(25.9 \pm 6.8) \times(23.7 \pm 2.4)^{\mathrm{a}}$ & $43.2 \pm 3.7^{\mathrm{b}}$ \\
\hline
\end{tabular}

Note: Data are presented as mean \pm SD. The different letters within each column indicate a significant difference at $P<0.05$, by $t$ test, $n=6$.

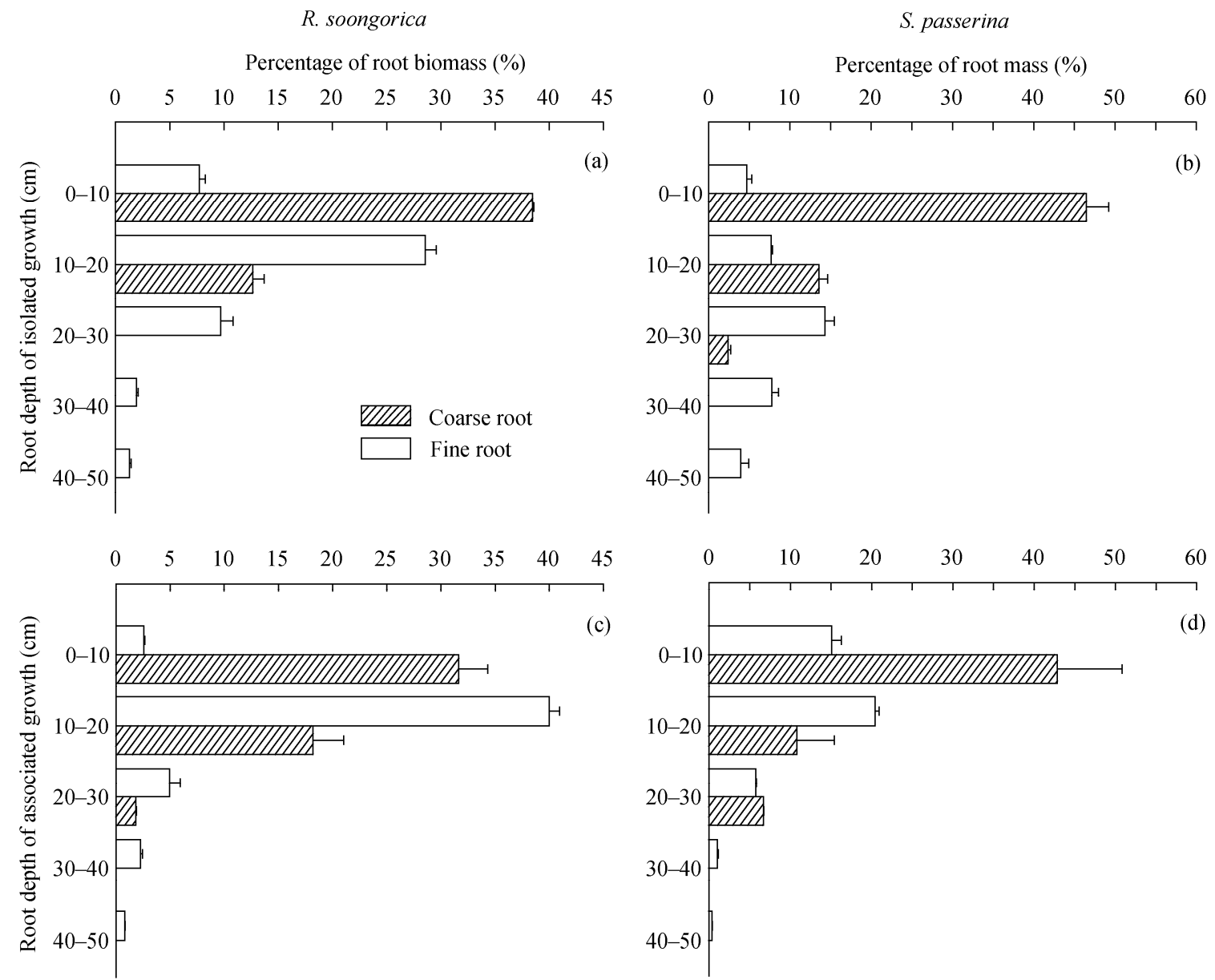

Fig. 3 Root biomass distribution of $R$. soongorica and S. passerina at different soil depths in isolated growth and associated growth, $n=6$.

Table 2 Plant biomass of $R$. soongorica and $S$. passerina in the mixed community

\begin{tabular}{llcccc}
\hline Species & Growth form & Canopy biomass $(\mathrm{g})$ & Root biomass $(\mathrm{g})$ & Total biomass $(\mathrm{g})$ & Root/canopy \\
\hline \multirow{2}{*}{ R. soongorica } & Isolated & $13.33 \pm 2.96^{\mathrm{a}}$ & $9.36 \pm 0.85^{\mathrm{a}}$ & $22.69 \pm 2.56^{\mathrm{a}}$ & $0.70^{\mathrm{a}}$ \\
& Associated & $15.25 \pm 2.46^{\mathrm{a}}$ & $5.68 \pm 0.59^{\mathrm{b}}$ & $20.93 \pm 2.93^{\mathrm{a}}$ & $0.37^{\mathrm{b}}$ \\
\multirow{2}{*}{ S. passerina } & Isolated & $41.98 \pm 0.39^{\mathrm{a}}$ & $6.20 \pm 0.25^{\mathrm{a}}$ & $48.18 \pm 0.64^{\mathrm{a}}$ & $0.15^{\mathrm{a}}$ \\
& Associated & $43.04 \pm 2.49^{\mathrm{a}}$ & $3.54 \pm 0.38^{\mathrm{b}}$ & $46.57 \pm 2.25^{\mathrm{a}}$ & $0.08^{\mathrm{b}}$ \\
\hline
\end{tabular}

Note: The different letters within each column and for each species indicate a significant difference at $P<0.05$, by $t$ test. Data are presented as mean \pm SD, $n=6$.

\section{Discussion}

Our data showed that $R$. soongorica and S. passerina possessed different root systems (Table 1), which was connected with plant growth forms (Schenk and
Jackson, 2002), suggesting that shrubs tend to have deep root systems, while semi-shrubs possess shallow and spread root systems. Due to the fact that the soil water in desert habitats mainly depends on rainfall and most of the soil water was focused on the shallow 

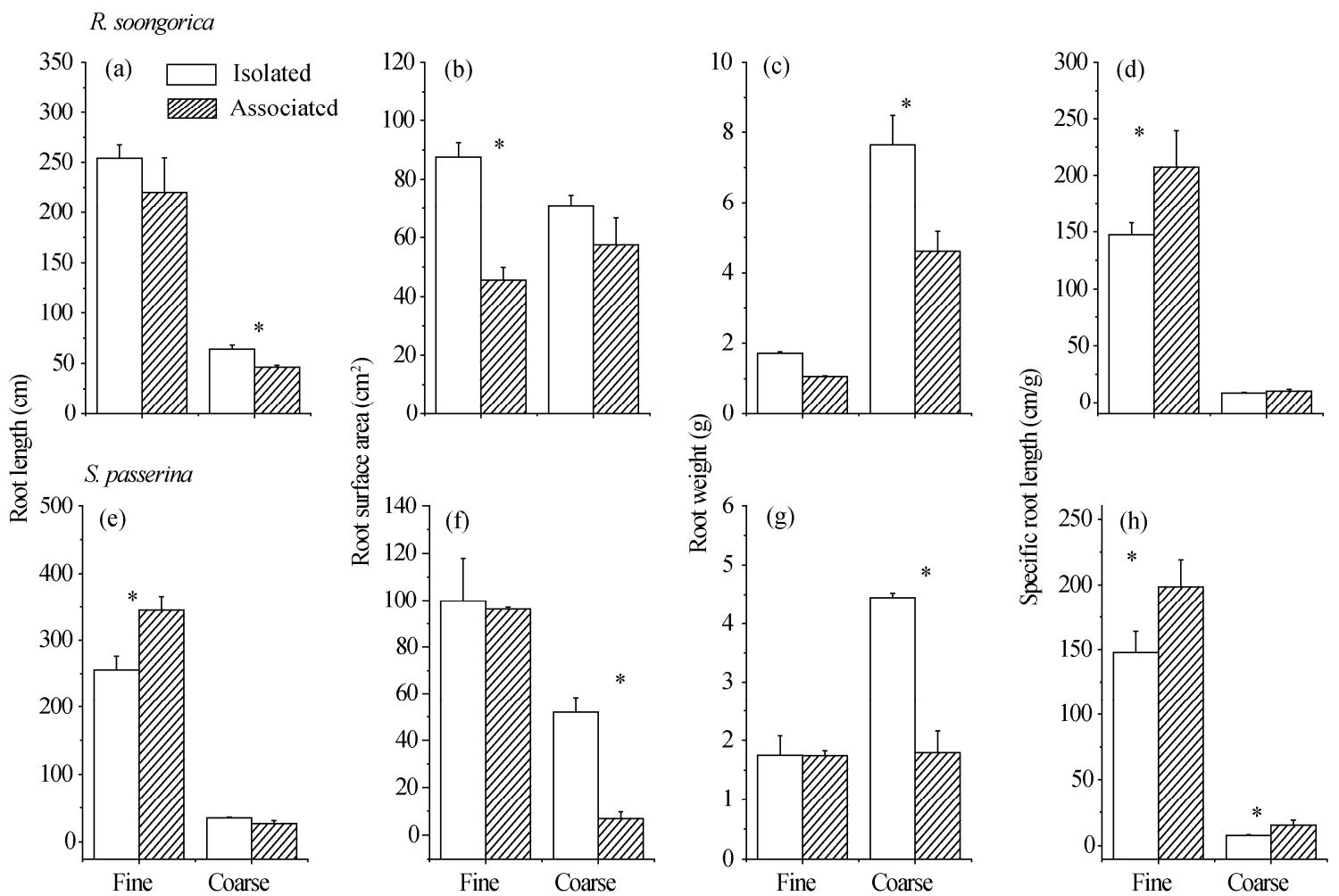

Fig. 4 Root traits of $R$. soongorica and S. passerina in isolated growth and associated growth. The significant differences within each root trait and for each root type are marked by asterisks ( $t$ test, $P<0.05), n=6$.

Table 3 Ratios of fine roots to coarse roots for R. soongorica and S. passerina in isolated growth and associated growth

\begin{tabular}{llcccc}
\hline Species & Growth form & $\mathrm{R}_{\mathrm{RL}}$ & $\mathrm{R}_{\mathrm{RSA}}$ & $\mathrm{R}_{\mathrm{RW}}$ & $\mathrm{R}_{\mathrm{SRL}}$ \\
\hline \multirow{2}{*}{ R. soongorica } & Isolated & $3.97 \pm 0.25^{\mathrm{a}}$ & $1.23 \pm 0.01^{\mathrm{a}}$ & $0.23 \pm 0.02^{\mathrm{a}}$ & $17.54 \pm 1.10^{\mathrm{a}}$ \\
& Associated & $4.75 \pm 0.33^{\mathrm{b}}$ & $0.81 \pm 0.09^{\mathrm{b}}$ & $0.23 \pm 0.02^{\mathrm{a}}$ & $20.65 \pm 1.63^{\mathrm{a}}$ \\
\multirow{2}{*}{ S. passerina } & Isolated & $7.34 \pm 0.33^{\mathrm{a}}$ & $1.91 \pm 0.12^{\mathrm{a}}$ & $0.40 \pm 0.08^{\mathrm{a}}$ & $18.98 \pm 1.10^{\mathrm{a}}$ \\
& Associated & $13.44 \pm 3.09^{\mathrm{b}}$ & $4.15 \pm 0.51^{\mathrm{b}}$ & $1.01 \pm 0.24^{\mathrm{b}}$ & $13.94 \pm 1.16^{\mathrm{b}}$ \\
\hline
\end{tabular}

Note: RL, root length; RSA, root surface area; RW, root weight; SRL, specific root length. The different letters within each column and for each species indicate significant difference at $P<0.05$, by $t$ test. Data are presented as mean $\pm \mathrm{SD}, n=6$.
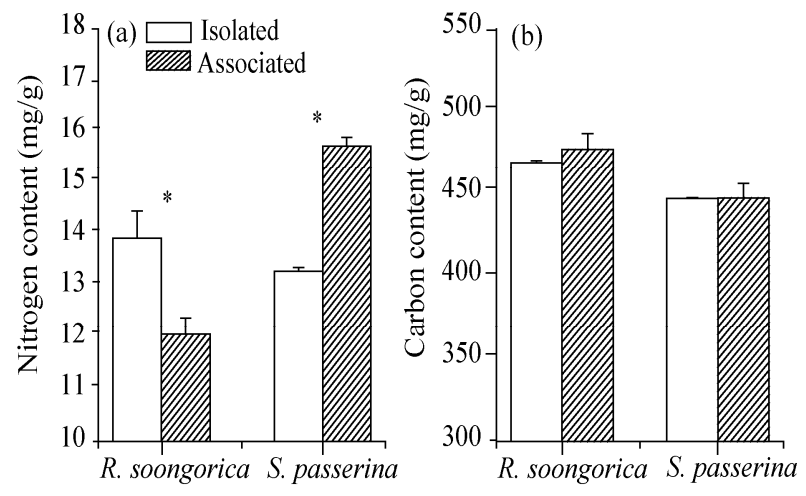

Fig. 5 Root $\mathrm{N}$ and $\mathrm{C}$ contents of $R$. soongorica and S. passerina in isolated growth and associated growth. The significant differences for each species are marked by asterisks ( $t$ test, $P<0.05)$, $n=6$.

soil layer (Fig. 2), about $90 \%$ of the total roots of $R$. soongorica and $S$. passerina were distributed in the top $30 \mathrm{~cm}$ soil depth (Fig. 3).

In the present study, most of the fine roots of $R$. soongorica and $S$. passerina in associated growth were overlapped in the $10-20 \mathrm{~cm}$ soil layer, while they were distributed in different soil layers in isolated growth, with $R$. soongorica in the $10-20 \mathrm{~cm}$ and $S$. passerina in the 20-30 cm, respectively (Fig. 3). This explains the fact that the interspecific interaction occurred between the roots in both species in associated growth, which was related to the changed microclimate due to the competition for limited water in associated growth. Our $\delta^{13} \mathrm{C}$ values $(-24.63 \%$ and $-24.98 \%$ for $R$. soongorica and $-17.38 \%$ and $-16.63 \%$ for $S$. passerina in isolated growth and associated growth, respectively) showed that the soil water condition in associated growth was relatively 
better for $R$. soongorica and worse for S. passerina. This may be the reason for the facilitated photosynthesis in $R$. soongorica and the decreased photosynthesis in S. passerina in associated growth ( $\mathrm{Su}$ et al., 2012). In order to compete with $R$. soongorica for water in shallow soil, $S$. passerina developed more fine roots in the top soil. Moreover, in associated growth, most of the fine roots in $R$. soongorica and $S$. passerina preferred to be overlapped in the shallow soil rather than show separated root distribution, which enhanced the overlapped fine root growth at the 10-20 cm soil depth. This phenomenon was identified by a previous study (de Kroon, 2007), which indicated that the mixed roots of genetically different plants stimulated the root growth and invested more biomass in the fine roots. The larger root mass would eventually exploit a larger part of the contested soil resources, resulting in enhanced competitive ability. Similarly, the greater ratios of fine roots to coarse roots in $S$. passerina in associated growth (Table 3 ) also offset the disadvantageous water conditions and elevated resource acquisition. Li et al. (2006) also suggested that crops induce more roots and explore a larger soil volume in mixtures than in monoculture, and obtain a higher yield.

The microclimate change in associated growth also played an important role in plant root morphology. $R$. soongorica showed lower RL, RSA and RW in associated growth than in isolated growth for either fine roots or coarse roots, while $S$. passerina showed higher RL in associated growth than in isolated growth (Fig. 4). The reason for this was that the root spread in $S$. passerina was greater than that in $R$. soongorica (Table 1), thus the greater number of overlapped roots of both species in associated growth caused the roots in $R$. soongorica to be surrounded and protected by the roots in $S$. passerina, owing that the soil structure (e.g. soil compaction) near the roots in $R$. soongorica was ameliorated and loosened for water and nutrient absorption, and meanwhile the fine roots in $R$. soongorica could avoid being damaged by the high amount of gravel in the soil. With an improved microenvironment around the roots in $R$. soongorica, it was not necessary to increase RL and RSA for water and nutrient absorption at the cost of greater investment in the root establishment in the resource-limited environment (Figs. $4 \mathrm{a}-\mathrm{c}$ ). The same is true with the lower root $\mathrm{N}$ content in $R$. soongorica in associated growth than in isolated growth (Fig. 5a) due to the great influence of $\mathrm{N}$ in root construction and absorption area and ability improvement (Marschner et al., 1996). Moreover, the lower root $\mathrm{N}$ content in $R$. soongorica may be related to the facilitative photosynthesis in $R$. soongorica in associated growth ( $\mathrm{Su}$ et al., 2012), and most of the $\mathrm{N}$ content was transported to the canopy for the increased photosynthesis. However, the competition in resource utility in associated growth resulted in the relatively more severe water and nutrient deficit around the roots in $S$. passerina, thus the fine roots in S. passerina were lengthened to capture more water and nutrients $(\mathrm{N})$ from distant sites (Figs. $4 \mathrm{e}$ and 5a), and less $\mathrm{N}$ content was transported to the canopy. This led to the declined photosynthesis in S. passerina in associated growth (Su et al., 2012).

In addition, species with a higher SRL may be at an advantage in exploiting pulses of water or nutrients in the soil (Eissenstat, 1991; Rieger and Litvin, 1999; Huang and Eissenstat, 2000; Withington et al., 2006). In the present study, the fine roots with a significantly higher SRL in both $R$. soongorica and S. passerina in associated growth (Figs. 4d and h) would induce an increase in plant capacity for water and nutrient acquirement. Both species adapted to the infertile and arid habitat more effectively in associated growth by changing their root morphology rather than increasing root resource investment to exploit nutrients and water.

The allocation of resources among plant tissues represents the largest transfer of resources a plant makes (Poorter et al., 1990; Law et al., 1999). The root/canopy ratios in $R$. soongorica and $S$. passerina were much lower in associated growth than in isolated growth (Table 2), and the ratios of fine roots to coarse roots were higher in associated growth (Table 3), illustrating that plant allocated more nutrients to canopy establishment for physiological metabolism in associated growth, and the capacity of roots for water and nutrient acquirement was supplemented by the larger proportion of fine roots in the total roots, because fine roots are responsible for water and nutrient absorption, and coarse roots are in charge of water and nutrient transport and nutrient storage. In addition, $R$. soongorica and $S$. passerina showed a significant decrease in underground biomass rather than in aboveground bi- 
omass in associated growth compared with isolated growth (Table 2). This signified that the interspecific relationship between the two species was more influenced by roots than by canopy in associated growth, which coincided with previous studies (Yeaton and Esler, 1990; Esler and Cowling, 1993; Carrick, 2003).

\section{Conclusions}

$R$. soongorica and $S$. passerina maximized the biomass accumulation at a lower cost of root establishment investment by coordinating the root/canopy ratio and root morphological characteristics under the interspecific facilitation in associated growth. In associated growth, the root systems of both species tended to be overlapped in the 10-20 cm soil layer rather than to be distributed separately. Although their root/canopy ratios reduced, both species showed an increase in SRL in the fine roots in associated growth. $S$. passerina also had an increase in $\mathrm{N}$ content and length in the fine roots. The results showed that the root growth of $S$. passerina was facilitated for water and nutrient exploration under the interaction of the overlapped roots in both species in associated growth, and higher SRL made both species adapt more effectively in the infertile soil in the desert ecosystem.

\section{Acknowledgements}

We are grateful for the financial support by the National Natural Science Foundation of China (91025026, 31070359) and the National Basic Research Program of China (Y31JA61001). The authors gratefully acknowledge the comments from the anonymous reviewers.

\section{References}

Aerts R. 1998. Interspecific competition in natural plant communities: Mechanisms, trade-offs, and plant-soil feedbacks. Journal of Experimental Botany, 49: 39.

Aerts R, Chapin III F S. 1999. The mineral nutrition of wild plants revisited: a re-evaluation of processes and patterns. Advances in Ecological Research, 30: 1-67.

Bertness M D, Callaway R. 1994. Positive interactions in communities. Trends in Ecology and Evolution, 9: 191-193.

Bertness M D, Ewanchuk P J. 2002. Latitudinal and climate-driven variation in the strength and nature of biological interactions in New England salt marshes. Oecologia, 132: 392-401.

Carrick P J. 2003. Competitive and facilitative relationships among three shrub species, and the role of browsing intensity and rooting depth in the Succulent Karoo, South Africa. Journal of Vegetation Science, 14:
761-772.

Cavieres L, Arroyo M T K, Penaloza A, et al. 2002. Nurse effect of Bolax gummifera cushion plants in the alpine vegetation of the Chilean Patagonian Andes. Journal of Vegetation Science, 13: 547-554.

Craine J M, Wedin D A, Chapin F S, et al. 2003. Relationship between the structure of root systems and resource use for 11 North American grassland plants. Plant Ecology, 165: 85-100.

de Kroon H. 2007. Ecology-How do roots interact? Science, 318: 1562-1563.

Eissenstat D M. 1991. On the relationship between specific root length and the rate of root proliferation: a field study using citrus rootstocks. New Phytologist, 118: 63-68.

Esler K J, Cowling R M. 1993. Edaphic factors and competition as determinants of pattern in South African karoo vegetation. South African Journal of Botany, 59: 287-295.

Franco A C, Nobel P S. 1989. Effect of nurse plants on the microhabitat and growth of cacti. Journal of Ecology, 77: 870-886.

Gomez-Aparcio L, Zamora R, Gomez J M, et al. 2004. Applying plant facilitation to forest restoration: a meta-analysis of the use of shrubs as nurse plants. Ecological Applications, 14: 1128-1138.

Hogh-Jensen H, Schjoerring J K. 2000. Below-ground nitrogen transfer between different grassland species: direct quantification by ${ }^{15} \mathrm{~N}$ leaf feeding compared with indirect dilution of soil ${ }^{15} \mathrm{~N}$. Plant and Soil, 227: 171-183.

Holl K D. 2002. Effect of shrubs on tree seedling establishment in an abandoned tropical pasture. Journal of Ecology, 90: 179-187.

Huang B R, Eissenstat D M. 2000. Linking hydraulic conductivity to anatomy in plants that vary in specific root length. Journal of the American Society for Horticultural Science, 125: 260-264.

Keddy P A. 1989. Competition. London: Chapman and Hall.

Larrea-Alcázar D M, López R P, Barrientos D. 2005. The nurse-plant effect of Prosopis flexuosa DC (Leg. mim.) in a dry valley of the Bolivian Andes. Ecotropicos, 18: 89-95.

Law B E, Ryan M G, Anthoni P M. 1999. Seasonal and annual respiration of a ponderosa pine ecosystem. Global Change Biology, 5: $169-182$.

Li L, Sun J H, Zhang F S, et al. 2006. Root distribution and interactions between intercropped species. Oecologia, 147: 280-290.

Liu J L, Li F R, Liu C A, et al. 2012. Influences of shrub vegetation on distribution and diversity of a ground beetle community in a Gobi desert ecosystem. Biodiversity and Conservation, 21: 2601-2619.

Maestre F T, Bautista S, Cortina J. 2003. Positive, negative, and net effects in grass-shrub interactions in Mediterranean semiarid grasslands. Ecology, 84: 3186-3197.

Marschner H, Kirkby E A, Cakmak I. 1996. Effect of mineral nutritional status on shoot-root partitioning of photoassimilates and cycling of mineral nutrients. Journal of Experimental Botany, 47: 1255-1263.

Moro M J, Pugnaire F I, Haase P, et al. 1997. Mechanisms of interaction between a leguminous shrub and its understorey in a semi-arid environment. Ecography, 20: 175-184.

Oesterheld M, Oyarzabal M. 2004. Grass-to-grass protection from grazing in a semi-arid steppe. Facilitation, competition, and mass effect. Oikos, 107: 576-582. 
Poorter H, Remkes C, Lambers H. 1990. Carbon and nitrogen economy of 24 wild species differing in relative growth rate. Plant Physiology, 94: 621-627.

Pugnaire F I, Luque M T. 2001. Changes in plant interactions along a gradient of environmental stress. Oikos, 93: 42-49.

Qiu M X, Liu J Q. 1982. The study on the plant community of Salsola passerina. Acta Ecologica Sinica, 2: 311-318.

Raffaele E, Veblen T T. 1998. Facilitation by nurse shrubs of resprouting behavior in a post-fire shrubland in northern Patagonia, Argentina. Journal of Vegetation Science, 9: 693-698.

Rieger M, Litvin P. 1999. Root system hydraulic conductivity in species with contrasting root anatomy. Journal of Experimental Botany, 50: 201-209.

Rossi B E, Villagra P E. 2003. Effects of Prosopis flexuosa on soil properties and the spatial pattern of understorey species in arid Argentina. Journal of Vegetation Science, 14: 543-550.

Schenk H J, Jackson R B. 2002. Rooting depths, lateral root spreads and below-ground/above-ground allometries of plants in water-limited ecosystems. Journal of Ecology, 90: 480-494.

Shiponeni N, Allsopp N, Carrick P J, et al. 2011. Competitive interactions between grass and succulent shrubs at the ecotone between an arid grassland and succulent shrubland in the Karoo. Plant Ecology, 212: 795-808.

Su P X, Yan Q D, Xie T T, et al. 2012. Associated growth of $C_{3}$ and $C_{4}$ desert plants helps the $C_{3}$ species at the cost of the $C_{4}$ species. Acta Physiologiae Plantarum, 34: 2057-2068.

Trumbore S E, Gaudinski J B. 2003. The secret lives of roots. Science, 302: 1344-1345.

Wilcox C S, Ferguson J W, Fernandez G C J, et al. 2004. Fine root growth dynamics of four Mojave Desert shrubs as related to soil moisture and microsite. Journal of Arid Environments, 56: 129-148.

Withington J M, Reich P B, Oleksyn J, et al. 2006. Comparisons of structure and life span in roots and leaves among temperate trees. Ecological Monographs, 76: 381-397.

Yan Q D, Su P X, Gao S. 2012. Response of photosynthetic characteristics of $\mathrm{C}_{3}$ desert plant Reaumuria soongorica and $\mathrm{C}_{4}$ desert plant Salsola passerina to different drought degrees. Journal of Desert Research, 32: 364-371.

Yeaton R I, Esler K J. 1990. The dynamics of a succulent karoo vegetation-a study of species association and recruitment. Vegetation, 88: 103-113. 